\title{
MOLECULAR, BACTERIOLOGICAL AND CLINICAL PATHOLOGICAL STUDIES ON PNEUMONIC CALVES WITH SPECIAL REFERENCE TO ANTIBIOTIC RESISTANCE GENES
}

\author{
HALA A. ABD EL-HAMED ${ }^{1}$ and GHADA A. IBRAHIM ${ }^{2}$ \\ ${ }^{1}$ Clinicalpathology, Animal Health Research Institute, Egypt \\ ${ }^{2}$ Bacteriology Units Ismailia, Provincial Laboratories, Animal Health Research Institute, Egypt
}

Received: 28 September 2017; Accepted: 31 October 2017

\begin{abstract}
The aim of the present study was to study the bacterial investigation of pneumonic calves, antibiotic susceptibility testing and analysis of some virulence and antibiotic resistance genes for the recovered isolates and evaluation of the changes of haematological indices and selected serum biochemistry variables. Bacteriological examination of nasal swabs of 40 apparently healthy and 90 pneumonic calves revealed that $E$. coli was the prominent pathogen (34.6\%) followed by S. aureus (28.5\%) and Past. Multicoda (13.1\%). Antibiotic sensitivity testing exhibited high resistance rates of E. coli and $S$. Aureus isolates against the most used antibiotics. Past. Multocida isolates were of high sensitivity rate against most antibiotics except some resistance for tetracycline, enerofloxacin and norofloxacin. Both iss and pap C virulence genes of E. coli were detected in $80 \%$ and $60 \%$ of the examined isolates, respectively. High prevalence rate of virulence genes (spa, clfA) and (Tox A and kmt1) of $S$. aureus and Past. multocida recovered isolates was recorded. Genotypic detection of antibiotic resistant genes of the most yielded isolates was discussed in details. In pneumonic calves, there were significant decreases in RBCs, $\mathrm{Hb}$ and PCV than that of healthy one. The significant increase in WBCs with neutrophilia was detected as well as significant decrease in lymphocyte count. Serum biochemical parameters revealed significant increase in globulin, AST, ALT, urea, creatinine, $\mathrm{P}$ and $\mathrm{K}$, while albumin, glucose, $\mathrm{Fe}, \mathrm{Mg}$ and $\mathrm{Ca}$ were significantly decreased.
\end{abstract}

Key wards: Bacteriology, virulence, antibiotics, PCR, hematology, biochemical, Bovine, bronchopneumonia.

\section{INTRODUCTION}

Respiratory infections are responsible for 37$52 \%$ losses in cattle. Unfortunately, Calves experienced pneumonia at early age might have severe depression in the future in the production capabilities causing severe economic costs (Sayed and Zaitoun, 2009 and Griffin et al., 2010).

Bacteria and viruses in combination with stress factors are the key in triggering acute respiratory infections usually bacteria act as the second invaders to worsen the ill-animal's condition (Yousef et al., 2013). The most bacterial causes include: Staphelococcus aureus, Staphelococcus Pneumonae, Escherichia coli, pseudomonas spp., Klebsiella spp, Mycoplasma haemolytica and Pasterella multocida.

Corresponding author: Dr. GHADA A. IBRAHIM

E-mail address: g_abdelaall@yahoo.com,

Present address: Bacteriology Units Ismailia, Provincial Laboratories, Animal Health Research Institute, Egypt.
The emergence of antibiotic resistant pathogenic bacteria has become a serious problem (French, 2005). The presence of resistant bacteria poses a risk to humans as they may act as resistance reservoirs, contributing to the maintenance and spread of antibiotic resistance genes (Goni-Urizza et al., 2000).

Clinical signs of respiratory disease in a group of calves are discordant. They includes: elevated rectal temperature, frequent coughing, muco-purulent nasal/ocular discharge, lethargy, loss of appetite and frequent lying down, exaggerated vesicular sound and moist rales with frictional sound may be heard (NADIS, 2014).

Almujalli et al. (2015) indicated that leukocytosis with neutrophilia was a hematological finding associated with pneumonia in calves. Moreover, there was a significant elevation in the levels of ALT, AST, ALP and AGP with significant decrease in levels of total protein, albumin in pneumonic calves in comparison with control calves. Saleh and Allam, (2014) revealed that the serum enzyme activity of ALT and AST were elevated $(\mathrm{P}<0.05)$ in sheep with pneumonia. Furthermore, their results added that there also a significant $(\mathrm{P}<0.05)$ decrease in serum 
concentration of albumin in association with a significant $(\mathrm{P}<0.05)$ increase in serum levels of gamma globulins $(\gamma$-Glob. $)$ in the examined pneumonic sheep. The serum biochemical change of pneumonic goat due to Pasteurlla multocida indicates significantly lower in $\mathrm{Ca}$ and $\mathrm{Mg}$ levels and increase in the concentration of inorganic phosphorus in comparison with the healthy goat (Sadeghian et al., 2011). A significant association with blood sample collection day and a decrease of $\mathrm{Cl}, \mathrm{K}$, and $\mathrm{P}$ concentrations and interactions between blood sample collection day and the severity of pneumonia in $\mathrm{Ca}$ and $\mathrm{Na}$ concentrations in calves after experimentally induced pneumonia, found (Fraser et al., 2014). The available data on the effect of respiratory disease on the mineral status, mainly trace elements, in calves were few.

Therefore, this work aims to investigate the clinical picture, evaluate the hemato-biochemical alterations and pulmonary function tests in pneumonic calves with reference to their microbial causes and their virulence factors. The current status of drugs sensitivity and resistance patterns using PCR technique in the diseased calves is also assessed.

\section{MATERIALS AND METHODS}

1. Animals: One-hundred and thirty Friesian calves from different farms belonging to Ismailia Governorate, Egypt, aged 2 to 9 months and their weights ranged from $60-130 \mathrm{~kg}$ were clinically examined they classified into 2 groups: The $1^{\text {st }}$ consisted of 40 apparently healthy calves that didn't show any diseased condition and didn't expose to any treatment; they were kept as a control calves. The $2^{\text {nd }}$ group consisted of 90 calves show respiratory manifestation presenting clinical signs of pneumonia including fever $\left(39.7 \pm 0.71{ }^{\circ} \mathrm{C}\right)$, dyspnea $(\mathrm{n}=50)$, mouth breathing, nasal discharge $(\mathrm{n}=50)$, coughing $(n=50)$, depression $(n=50)$, weight loss, increased respiratory rate $(22.6 \pm 2.9 \mathrm{~min}-1)$.

2. Clinical examination: All animals were subjected to clinical examination according to Rosenberger et al. (1979). Data concerned with the case history, clinical findings, and medical record for each calf were illustrated in (Table 11).

\section{Samples:}

a) For bacteriological examination: Nasal swabs and blood smears samples were collected from the examined calves (90 pneumonic and 40 apparently healthy calves) from different farms in Ismailia Governorate in Egypt. Samples were individually collected using sterile swabs with nutrient broth as a transport medium then labeled and transported immediately to the bacteriological laboratory for examination. b) For haematological examination: Blood samples were collected from both groups and were divided into three parts. The first part was collected on (EDTA) for hemogram. The second part was collected on heparin (20 IU/ $\mathrm{ml}$ ) for measuring of plasma values of fibrinogen $(F)$ The samples were placed in a bed of crushed ice, taken immediately to the laboratory for analysis. The third part was placed in a plain centrifuge tubes for separation of serum. The serum samples were stored at $-20^{\circ} \mathrm{C}$ until assayed for the rest biochemical parameters.

4. Hematological studies: The evaluated hematological parameters in this study included estimation of red blood cell count (RBCs), hemoglobin concentration $(\mathrm{Hb})$, packed cell volume (PCV), Total leukocytic count (TLC) and differential leukocytic counts. Mean corpuscular volume (MCV), mean corpuscular hemoglobin $(\mathrm{MCH})$ and mean corpuscular hemoglobin concentration $(\mathrm{MCHC})$ were calculated. These parameters were performed according to the routine hematological procedures adopted by Feldman et al. (2000).

5. Biochemical examination: Serum protein was determined according to method illustrated by Doumas et al. (1981). Albumin and globulins were separated by cellulose acetate electrophoresis using Helena system (Helena France) (Batavani et al., 2006). Serum enzymes AST was estimated according to method previously described by Kachmar and Moss (1987), ALT was estimated according to method previously described by Bergmeyer and Harder (1986). Serum creatinine was determined using kits (Bio-labo, France) according to method described by (Young, 1995). Analysis of urea was carried out by using commercial test kits (Vitro Scient, Egypt) according to method described by (Rock et al., 1987). Sodium and potassium values were estimated by using of atomic absorption spectrophotometer (Perkin-Elmer, 1967). Serum concentrations of calcium $(\mathrm{Ca}, \mathrm{mmol} / \mathrm{l})$, magnesium ( $\mathrm{Mg}, \mathrm{mmol} / \mathrm{l})$ glucose (Glu, mmol/l), phosphorus (P, mmol/l), creatine phosphokinase (CK, $\mu \mathrm{kat} / \mathrm{l})$ and iron $(\mathrm{Fe}, \mu \mathrm{mol} / \mathrm{l})$ were analysed by atomic absorption spectrophotometer (A Analyst 100, Perkin Elmer). Plasma fibrinogen was detected by Spectrophotometric method using commercial kits of Boehringer Ingelheim (Germany).

6. Isolation and identification of bacterial causes: All nasal swabs samples were transported on nutrient broth medium, cultivated and aerobically incubated at $37{ }^{\circ} \mathrm{C}$ for 24 hours. In $2^{\text {nd }}$ day, they were streaked on nutrient agar, $10 \%$ sheep blood agar and MacConkey's (Oxoid) agar media for each sample for cultivation of both Gram positive and Gram negative bacteria. The cultured plates were incubated aerobically overnight at $37{ }^{\circ} \mathrm{C}$ for 24 hours. Pure colonies from the recovered isolates were sub- 
cultured on selective agar media: Eosin Methylene Blue and Mannitol salt agar with aerobic incubation at $37^{\circ} \mathrm{c}$ for 24 hours. Microscopic examination of the recovered isolates with Gram stain was done. However, blood smears were stained with Gimsa stain for identification of Pasteurella spp. The suspected colonies were purified and biochemically tested based on the criteria of Quinn et al. (2002). Catalase, Oxidase, indole, motility, Triple Sugar Iron agar slants, citrate utilization, methyl red and urea production. The Identified $E$. coli isolates were serotyped by commercially available kits using polyvalent and monovalent antisera $\mathrm{O}$ and $\mathrm{K}$ (Test Sera Enteroclon, Anti -Coli, SIFIN Berlin, Germany) at Animal Health Research Insititute, Serlogy Unit, Dokki, Giza. All the isolates were stored in brain heart infusion broth with $30 \%$ glycerol at $-70^{\circ} \mathrm{C}$ until required.

7. Pathogenicity test for Past. Multocida isolates (Buxton, and Fraser, 1977): Three Swiss mice weighting about $15-20 \mathrm{~g}$ for each isolate were used. All mice were injected intrapritoneally with $0.1 \mathrm{ml}$ of the cultured bacterial suspension with infectious dose of $\left(1.5 \times 10^{8} \mathrm{cfu}\right)$. Three mice for each isolate were used as a control (which was injected I/P with $0.1 \mathrm{ml}$ of sterile normal saline). All mice were kept under observation and mortality rate was recorded. Reisolation of the organism from the dead mice was carried out from heart blood and from spleen; liver and lung on $10 \%$ sheep blood agar medium as was previously mentioned. The blood films were prepared and stained with Gimsa stain for showing the characteristic features of Past. multocida organisms.

8. Antimicrobial susceptibility test: The susceptibility profiles of (E. coli, S. aureus and pasterella multicoda) isolates from pneumonic calves were performed using disk diffusion technique according to the procedures of (CLSI, 2011). Pure colonies were picked up, cultivated on Muller Hinton broth and incubated at $37^{\circ} \mathrm{C}$ for $24 \mathrm{~h}$ then compared with $0.5 \%$ of McFarland tube. Then the bacterial suspension was streaked on Mueller-Hinton agar plates using a dry sterile cotton swab and incubated at $37^{\circ} \mathrm{C}$ for $24 \mathrm{~h}$. The inhibition zone diameter of the cultured plates were recorded and measured. The following antibiotics were assayed: penicillin $(10 \mu \mathrm{g})$, amoxicillin+clavulanic acid $(10 \mu \mathrm{g})$, gentamicin $(120$ $\mu \mathrm{g}$ ), erythromycin $(15 \mu \mathrm{g})$, enrofloxacin (5 $\mu \mathrm{g})$, sulphamethoxazole $(25 \mu \mathrm{g})$, tetracycline $(10 \mu \mathrm{g})$, ciprofloxacin $(5 \mu \mathrm{g})$, and norofloxacin $(10 \mu \mathrm{g})$.

\section{Molecular identification of some virulence and} resistance genes:

DNA extraction: DNA extraction with modifications of 24 hours incubatedbuffered peptone suspensions of some isolated bacterial strains (E. coli, S. aureus and past. multicoda) according to the manufacturer's recommendations at RLQP (Reference Laboratory for Veterinary Quality Control on Poultry Production) was performed using the QIAamp DNA Mini kit (Qiagen, Germany, GmbH) for screening for some virulence and antibiotic resistant genes with conventional PCR. Briefly, $200 \mu \mathrm{l}$ of the sample suspension was incubated with $10 \mu$ l of proteinase $\mathrm{K}$ and $200 \mu \mathrm{l}$ of lysis buffer at $56 \mathrm{C}$ for $10 \mathrm{~min}$. After incubation, $200 \mu \mathrm{l}$ of $100 \%$ ethanol was added to the lysate. The sample was then washed and centrifuged following the manufacturer's recommendations. Nucleic acid was eluted with $100 \mu$ l of elution buffer provided in the kit. Oligonucleotides primers were supplied from metabion (Germany).

PCR amplification: Primers were utilized in a $25 \mu \mathrm{l}$ reaction containing $12.5 \mu \mathrm{l}$ of Emerald Amp Max PCR Master Mix (Takara, Japan), $1 \mu \mathrm{l}$ of each primer of 20 pmol concentrations, $4.5 \mu$ l of water, and $6 \mu \mathrm{l}$ of DNA template. The reaction was performed in an Appliedbiosystem 2720 thermal cycler.

Analysis of the PCR Products: The products of PCR were separated by electrophoresis on $1.5 \%$ agarose gel (Applichem, Germany, GmbH) in $1 \mathrm{x}$ TBE buffer at room temperature using gradients of $5 \mathrm{~V} / \mathrm{cm}$. For gel analysis, $20 \mu \mathrm{l}$ of the uniplex PCR products were loaded in each gel slot. Generuler 100 bp DNA Ladder (Fermentas, Germany) was used to determine the fragment sizes. The gel was photographed by a gel documentation system (Alpha Innotech, Biometra) and the data was analyzed through computer software (Sambrook et al., 1989). For each PCR experiment, appropriate positive and negative controls were included.

\section{Statistical Analysis}

Statistical analysis was performed using computer program statistical package for social science (SPSS) Leech et al. (2007). Results were expressed by mean \pm SEM and all the comparisons were done by ANOVA method and considered different when $\mathrm{p}<$ 0.01 . 
Table1: Oligonucleotide primer sequences of virulence genes of bacterial isolates.

\begin{tabular}{|c|c|c|c|c|}
\hline Bacterial species & Virulent gene & & Primer sequence (5-3) & Ref \\
\hline \multirow{4}{*}{ E.coli } & \multirow[t]{2}{*}{ Iss } & $\mathrm{F}$ & ATGTTATTTTCTGCCGCTCTG & \multirow{2}{*}{ Yaguchi et al., 2007} \\
\hline & & $\mathrm{R}$ & CTATTGTGAGCAATATACCC & \\
\hline & \multirow{2}{*}{ pap $C$} & $\mathrm{~F}$ & TGATATCACGCAGTCAGTAGC & \multirow{2}{*}{ Wen-jie et al., 2008} \\
\hline & & $\mathrm{R}$ & CCGGCCATATTCACATAA & \\
\hline \multirow{4}{*}{ S. aureus } & \multirow{2}{*}{ Spa } & $\mathrm{F}$ & TCA ACA AAG AAC AAC AAA ATG C & \multirow{2}{*}{ Wada et al., 2010} \\
\hline & & $\mathrm{R}$ & GCT TTC GGT GCT TGA GAT TC & \\
\hline & \multirow{2}{*}{ clfA } & $\mathrm{F}$ & GCAAAATCCAGCACAACAGGAAACGA & \multirow{2}{*}{ Mason et al., 2001} \\
\hline & & $\mathrm{R}$ & CTTGATCTCCAGCCATAATTGGTGG & \\
\hline \multirow{4}{*}{ Pasterella multicoda } & Tox A & $\mathrm{F}$ & CTTAGATGAGCGACAAGG & \multirow{2}{*}{ Tang et al., 2009} \\
\hline & (hyaD-hyaC) & $\mathrm{R}$ & GAATGCCACCTCTATAG & \\
\hline & \multirow{2}{*}{ Kmtl } & $\mathrm{F}$ & ATCCGCTATTTACCCAGTGG & \multirow{2}{*}{$\begin{array}{c}\text { Townsend et al. } \\
\text { (1998) }\end{array}$} \\
\hline & & $\mathrm{R}$ & GCTGTAAACGAACTCGCCAC & \\
\hline
\end{tabular}

\section{F: Forward R: Reverse}

Table 2: Oligonucleotide primer sequences of antibiotic resistance genes of isolates.

\begin{tabular}{|c|c|c|c|c|}
\hline \multirow{3}{*}{$\begin{array}{l}\text { Bacterial } \\
\text { species }\end{array}$} & Target gene & & Primers sequences & Reference \\
\hline & \multirow{2}{*}{ TetA } & $\mathrm{F}$ & GGTTCACTCGAACGACGTCA & \multirow{2}{*}{ Randall et al., 2004} \\
\hline & & $\mathrm{R}$ & CTGTCCGACAAGTTGCATGA & \\
\hline \multirow{4}{*}{ E.coli } & \multirow{2}{*}{$b l a_{T E M}$} & $\mathrm{~F}$ & ATCAGCAATAAACCAGC & \multirow{2}{*}{ Colom et al., 2003} \\
\hline & & $\mathrm{R}$ & CCCCGAAGAACGTTTTC & \\
\hline & \multirow{2}{*}{$q n r S$} & $\mathrm{~F}$ & ACGACATTCGTCAACTGCAA & \multirow{2}{*}{ Robicsek et al., 2006} \\
\hline & & $\mathrm{R}$ & TAAATTGGCACCCTGTAGGC & \\
\hline \multirow{4}{*}{ S.aureus } & \multirow{2}{*}{ NorA } & $\mathrm{F}$ & TTCACCAAGCCATCAAAAAG & \multirow{2}{*}{ Pourmand et al., 2014} \\
\hline & & $\mathrm{R}$ & CTTGCCTTTCTCCAGCAATA & \\
\hline & \multirow{2}{*}{ BlaZ } & $\mathrm{F}$ & ACTTCAACACCTGCTGCTTTC & \multirow{2}{*}{ Duran et al., 2012} \\
\hline & & $\mathrm{R}$ & TGACCACTTTTATCAGCAACC & \\
\hline
\end{tabular}

\section{F: Forward R: Reverse}

Table 3: Cycling conditions and predicted sizes of PCR products for virulence and antibiotic resistance gene.

\begin{tabular}{|c|c|c|c|c|c|c|}
\hline \multirow{2}{*}{$\begin{array}{l}\text { Target } \\
\text { gene }\end{array}$} & \multirow{2}{*}{$\begin{array}{c}\text { Initial } \\
\text { denaturation } \\
{ }^{\circ} \mathrm{C} / \mathrm{min}\end{array}$} & \multicolumn{3}{|c|}{$\begin{array}{c}\text { Actual cycles (35) } \\
{ }^{\circ} \mathrm{C} / \mathrm{sec}\end{array}$} & \multirow[t]{2}{*}{$\begin{array}{l}\text { Final extention } \\
{ }^{\circ} \mathrm{C} / \mathrm{min}\end{array}$} & \multirow{2}{*}{$\begin{array}{c}\text { Expected amplified } \\
\text { product } \\
\text { Size (bp) }\end{array}$} \\
\hline & & Denaturation & Annealing & Extension & & \\
\hline Iss & $94 / 5$ & $94 / 30$ & $54 / 30$ & $72 / 30$ & $72 / 10$ & 266 \\
\hline pap $C$ & $94 / 5$ & $94 / 30$ & $54 / 40$ & $72 / 45$ & $72 / 10$ & 501 \\
\hline TetA & $94 / 5$ & $94 / 30$ & $50 / 40$ & $72 / 45$ & $72 / 10$ & 576 \\
\hline bla & $94 / 5$ & $94 / 30$ & $54 / 40$ & $72 / 45$ & $72 / 10$ & 516 \\
\hline$q n r S$ & $94 / 5$ & $94 / 30$ & $55 / 40$ & $72 / 45$ & $72 / 10$ & 417 \\
\hline Spa & $94 / 5$ & $94 / 30$ & $55 / 30$ & $72 / 30$ & $72 / 10$ & 226 \\
\hline$C l f A$ & $94 / 5$ & $94 / 30$ & $55 / 45$ & $72 / 45$ & $72 / 10$ & 638 \\
\hline $\operatorname{Nor} A$ & $94 / 5$ & $94 / 30$ & $55 / 45$ & $72 / 45$ & $72 / 10$ & 620 \\
\hline BlaZ & $94 / 5$ & $94 / 30$ & $54 / 30$ & $72 / 30$ & $72 / 10$ & 173 \\
\hline $\operatorname{Tox} A$ & $94 / 5$ & $94 / 30$ & $54 / 30$ & $72 / 30$ & $72 / 5$ & 864 \\
\hline Kmt1 & $94 / 10$ & $94 / 60$ & $48 / 60$ & $72 / 60$ & $72 / 10$ & 460 \\
\hline
\end{tabular}




\section{RESULTS}

\section{Bacteriological examination of bacterial pathogens in calves:}

The present study recognized that E. coli $(34.6 \%), S$. aureus (28.5\%) and Pasterella multocida (13.1\%) were that most predominant isolated pneumonic bacterial pathogens among 40 apparently healthy and 90 pneumonic calves showing pneumonia and respiratory disorders (Table 4).

Phenotypic and cultural characterization of the recovered isolates: According to morphological and cultural characters, E. coli appear microscopically as Gram negative medium sized bacilli. It grows on macconky's agar medium as pink non-lactose fermenter colonies and gives the characteristic green metallic sheen appearance on EMB agar. Biochemically, E. coli isolates were indole positive, citrate negative, urease negative. Serotyping of the recovered $E$. coli isolates in this study revealed different serotypes (O143: H4, O1: H2, O63: H5, O157:H7, O158: H10, O119:H4, O86:H9 and O18:H6) (Table 5). In addition, S. aureus isolates were appeared microscopically, as Gram-positive cocci, non-motile, non-spore forming, non-capsulated and usually arranged in grapes like irregular clusters. They were $\beta$ - heamolytic and change the colour of (MSA) medium from pink to medium yellow due to sugar fermentation and acid production. Biochemical identification showed that they were sugar fermenters, catalase, coagulase, citrate and urease positive while negative for indole and oxidase tests. However, Past.multocida colonies exhibited smooth glistening and translucent on nutrient agar while they were non-hemolytic dewdrop like colonies on $10 \%$ sheep blood agar media but didn't grow on MacConkey agar media. They were Gram negative, coccobacilli and with biochemical identification, Past. Multocida were positive for indole, oxidase and catalase, while negative for citrate and methyl red tests. Concerning to, the results of pathogencity test of Past. multocida isolates in mice; they were highly pathogenic in mice producing acute septicemia and death within 24-48 hours post inoculation (Table 6). Bipolar organisms were clear microscopically in Giemsa stained smears that were prepared from heart blood of dead mice. Past.multocida was re-isolated from all inoculated mice from the blood, liver, spleen and lung samples on $10 \%$ Sheep blood agar and examined microscopically with Gimsa stain.

Antimicrobial resistance profile of the tested bacterial isolates: Table (7) indicated that E. coli isolates were of high resistance rates against amoxicillin+clavulanic acid, penicillin, ciprofloxacin and sulphamethoxazole $(100 \%)$ followed by tetracycline $(80 \%)$. S. aureus isolates showed high resistance levels to penicillin and norofloxacin $(100 \%)$ followed by tetracycline (90\%). However,
Past.multocida isolates exhibited high sensitive rates against most antibiotics were used however, they were resistant totetracycline $(41 \%)$ followed by enerofloxacin and norfloxacin antibiotics $(30 \%$ for each).

PCR screening for some specific virulence genes for the recovered isolates: Among ten $E$. coli examined isolates with conventional PCR in this study; iss and pap $\mathrm{C}$ virulence genes were detected in $90 \%$ and $60 \%$ of the isolates, respectively as shown in (Table 8) and (Fig.1, A \&B). The virulence genes of S. aureus (Spa and clfA) genes were found in $100 \%$ and $80 \%$ of PCR tested isolates, respectively (Fig.1, C\&D). In addition, PCR identification of some recovered Past. Multocida isolates with Tox A gene detected clear characteristic bands which were observed at 864 bp of (Fig.1,E) in all isolates. Also, kmt1 virulence gene was detected with PCR in $100 \%$ of the isolates (Fig.1,F) indicating their pathogenicity and virulence of Past. Multocida isolates.

Genotypic characterization of antibiotic resistance genes of the tested isolates: In the present study, the phenotypic resistance of $E$. coli isolates to amoxicillin-clavulanic acid and ciprofloxacin antibiotics could be explained by the presence of bla $_{\text {TEM }}$ and qnrS resistance genes among the twenty examined isolates $(100 \%$ for each) however, tetracycline resistant gene (tetA) was found in $80 \%$ of E. coli isolates as (Table 9). PCR amplifications of the resistance genes yielded the predicted amplicon sizes at 516 and 417 bp and 576 bp (Fig2. G\&H\&I). According to $S$. aueus isolates, NorA was exhibited in $100 \%$ of the examined isolates (Table 10) that they were phenotypically resistant to norofloxacin however, blaZ gene was detected in $90 \%$ of S. aueus PCR examined isolates (Fig2. J\&K).

The clinical signs in this study in Table (11) showed that a significant increase in both respiratory and heart rates in calves affected with pneumonia and wheezing with a high pitched breath sound was also detected during thoracic auscultation indicating severe lung injury. According to the hematological results were shown in Table (12), there was a significant $(\mathrm{P}<0.05)$ decrease in $\mathrm{RBC}$ s count and $\mathrm{Hb}$, $\mathrm{PCV}, \mathrm{MCV}, \mathrm{MCH}$ and $\mathrm{MCHC}$ values in the diseased group compared to the control. There was also seen significant $(\mathrm{P}<0.05)$ increase in TLC was seen in the diseased group with significant $(\mathrm{P}<0.05)$ increase in the mean values of neutrophilic, eosinophilic and monocytic counts. The mean values of lymphocytic count showed a significant $(\mathrm{P}<0.05)$ decrease in the diseased group while no changes were observed in the count of basophils. Also, the results of serum biochemical changes as shown in Table $(13,14 \& 15)$ clarified that significant $(\mathrm{P}<0.05)$ decreases were noticed in serum concentration of albumin and $\mathrm{A} / \mathrm{G}$ ratio in diseased group compared to the control one but serum values of total proteins and globulins 
showed a significant increase. Serum concentrations of urea, creatinine and serum enzymatic activities of ALT and AST were significantly $(\mathrm{P}<0.05)$ increased in the diseased calves. The mean values of serum levels of $\mathrm{P}$ and $\mathrm{Na}$ were significantly $(\mathrm{P}<0.05)$ lower in the diseased calves.

Table 4: Isolation rate of bacterial species in apparently healthy and pneumonic calves.

\begin{tabular}{ccccccccccc}
\hline Bacterial species & \multicolumn{3}{c}{$\begin{array}{c}\text { Apparently healthy calves } \\
\text { (40) }\end{array}$} & \multicolumn{4}{c}{ Pneumonic calves (90) } & \multicolumn{2}{c}{ Total isolates } \\
\cline { 2 - 14 } & $\begin{array}{c}\text { Nasal } \\
\text { swabs }\end{array}$ & $\begin{array}{c}\text { Blood } \\
\text { smears }\end{array}$ & $\begin{array}{c}\text { Total } \\
\text { No. }\end{array}$ & $\%$ & $\begin{array}{c}\text { Nasal } \\
\text { swabs }\end{array}$ & $\begin{array}{c}\text { Blood } \\
\text { smears }\end{array}$ & $\begin{array}{c}\text { Total } \\
\text { No. }\end{array}$ & $\%$ & $\begin{array}{c}\text { Total } \\
\text { No. }\end{array}$ & Total \% \\
\hline E. coli & 12 & - & $12 / 40$ & $30 \%$ & 25 & 8 & $33 / 90$ & $36.7 \%$ & $45 / 130$ & $(34.6 \%)$ \\
\hline S. aureus & 10 & - & $10 / 40$ & $25 \%$ & 16 & 11 & $27 / 90$ & $30 \%$ & $37 / 130$ & $(28.5 \%)$ \\
\hline Past. multicoda & - & - & - & - & - & 17 & $17 / 90$ & $18.9 \%$ & $17 / 130$ & $(13.1 \%)$ \\
\hline
\end{tabular}

Table 5: prevalence of detected serotypes based on total number of E.coli isolates $(\mathrm{n}=45)$.

\begin{tabular}{|c|c|c|}
\hline Types of E.coli isolates & Serotypes & \% No. of isolates \\
\hline \multirow{8}{*}{ E.coli } & O143:H4 & $26 \%(12)$ \\
\hline & O158: H10 & $15.5 \%(7)$ \\
\hline & O119:H4 & $15.5 \%(7)$ \\
\hline & $\mathrm{O} 157: \mathrm{H7}$ & $11 \%(5)$ \\
\hline & O63:H5 & $9 \%(4)$ \\
\hline & O18:H6 & $7 \%(3)$ \\
\hline & $\mathrm{O} 1: \mathrm{H} 2$ & $4.5 \%(2)$ \\
\hline & O86:H9 & $4.5 \%(2)$ \\
\hline UNTYPABLE & & \\
\hline TOTAL & & \\
\hline
\end{tabular}

Table 6: Pathogencity test of the isolated Past. Multicoda strains in mice.

\begin{tabular}{|c|c|c|c|c|c|c|c|c|}
\hline \multirow{2}{*}{ Experimental mice } & \multirow{2}{*}{$\begin{array}{c}\text { No. of } \\
\text { isolates } \\
(17)\end{array}$} & \multirow{2}{*}{ Dose } & \multicolumn{4}{|c|}{ Time of death in hours } & \multicolumn{2}{|c|}{ Death rate } \\
\hline & & & Less than $24 \mathrm{~h}$ & $24 \mathrm{~h}$ & $48 h$ & $72 \mathrm{~h}$ & No. & $\%$ \\
\hline $\begin{array}{l}\text { No. of inoculated mice } \\
\qquad(\mathrm{n}=3)\end{array}$ & 51 & $1.5 \times 10^{8} \mathrm{cfu} \mathrm{I} / \mathrm{p}$ & 24 & 19 & 8 & - & 51 & $100 \%$ \\
\hline Control mice $(n=3)$ & - & sterile saline & - & - & - & - & - & - \\
\hline
\end{tabular}

Table 7: Antibiotic sensitivity patterns of most isolated bacterial species.

\begin{tabular}{|c|c|c|c|c|c|c|c|c|c|c|c|c|}
\hline \multirow[t]{2}{*}{ Antibiotics } & \multicolumn{4}{|c|}{$\begin{array}{c}\text { E.coli } \\
(45)\end{array}$} & \multicolumn{4}{|c|}{$\begin{array}{l}\text { S. aureus } \\
\text { (37) }\end{array}$} & \multicolumn{4}{|c|}{$\begin{array}{c}\text { Past. multocida } \\
\text { (17) }\end{array}$} \\
\hline & $S$ & $\%$ & $R$ & $\%$ & $S$ & $\%$ & $R$ & $\%$ & $S$ & $\%$ & $R$ & $\%$ \\
\hline Penicillin $(10 \mu \mathrm{g})$ & - & - & 45 & $100 \%$ & - & - & 37 & $100 \%$ & 14 & $82 \%$ & 3 & $18 \%$ \\
\hline $\begin{array}{c}\text { Amoxicillin+clavulanic } \\
\text { acid }(10 \mu \mathrm{g})\end{array}$ & - & - & 45 & $100 \%$ & 24 & $65 \%$ & 7 & $35 \%$ & 17 & $100 \%$ & - & - \\
\hline Gentamicin $(120 \mu \mathrm{g})$ & 16 & $34 \%$ & 29 & $66 \%$ & 37 & $100 \%$ & - & - & 17 & $100 \%$ & - & - \\
\hline Erythromycin $(15 \mu \mathrm{g})$ & 7 & $15 \%$ & 38 & $85 \%$ & 10 & $27 \%$ & 27 & $73 \%$ & 15 & $88 \%$ & 2 & $12 \%$ \\
\hline Sulphamethoxazole $(25 \mu \mathrm{g})$ & - & - & 45 & $100 \%$ & 33 & $90 \%$ & 4 & $10 \%$ & 16 & $94 \%$ & 1 & $6 \%$ \\
\hline Tetracycline $(10 \mu \mathrm{g})$ & 9 & $20 \%$ & 36 & $80 \%$ & 4 & $11 \%$ & 33 & $89 \%$ & 10 & $59 \%$ & 7 & $41 \%$ \\
\hline Enrofloxacin $(5 \mu \mathrm{g})$ & 20 & $45 \%$ & 25 & $55 \%$ & 3 & $8 \%$ & 34 & $92 \%$ & 12 & $71 \%$ & 5 & $29 \%$ \\
\hline Ciprofloxacin $(5 \mu \mathrm{g})$ & - & - & 45 & $100 \%$ & 28 & $76 \%$ & 9 & $24 \%$ & 14 & $82 \%$ & 3 & $18 \%$ \\
\hline Norfloxacin $(10 \mu \mathrm{g})$ & 11 & $25 \%$ & 34 & $75 \%$ & - & - & 37 & $100 \%$ & 7 & $70 \%$ & 3 & $30 \%$ \\
\hline
\end{tabular}


Table 8: The prevalence of virulence and antibiotic resistance genes among examined isolates.

\begin{tabular}{|c|c|c|c|}
\hline Gen & acterial species & & $\%$ No. of isolate strains \\
\hline \multirow{6}{*}{ Virulence genes } & \multirow[t]{2}{*}{ E. coli } & Iss & $80 \%$ \\
\hline & & PapC & $60 \%$ \\
\hline & \multirow{2}{*}{ S. aureus } & Spa & $100 \%$ \\
\hline & & ClfA & $80 \%$ \\
\hline & \multirow{2}{*}{ Past. multicoda } & $\operatorname{Tox} A$ & $100 \%$ \\
\hline & & $K m t_{1}$ & $100 \%$ \\
\hline \multirow{5}{*}{ Resistance genes } & \multirow{3}{*}{ E. coli } & Tet $A$ & $80 \%$ \\
\hline & & bla $_{T E M}$ & $100 \%$ \\
\hline & & Qnrs & $100 \%$ \\
\hline & \multirow{2}{*}{ S. aureus } & $\operatorname{Nor} A$ & $100 \%$ \\
\hline & & $b l a_{Z}$ & $90 \%$ \\
\hline
\end{tabular}

Table 9: Relation between resistance profiles and genotypic characterization of some virulence and antibiotic resistance genes of E.coli isolates.

\begin{tabular}{cccccccc}
\hline \multirow{2}{*}{ ID } & \multirow{2}{*}{ Serotype } & \multirow{2}{*}{ Resistance profile } & \multicolumn{2}{c}{ Virulence genes } & \multicolumn{2}{c}{ Antibiotic resistance genes } \\
\cline { 3 - 8 } & & & Iss & PapC & Tet A & bla $_{\text {TEM }}$ & qnrs \\
\hline 1 & O143:H4 & P, AMC,CIP, ENR, S, E, NOR & - & - & - & + & + \\
\hline 2 & O63:H5 & P, S, CN,TE, AMC, NOR, E,CIP & + & - & + & + & + \\
\hline 3 & O157:H7 & P, AMC,CIP, ENR, S, E, NOR,TE & + & + & + & + & + \\
\hline 4 & O158:H10 & P, AMC,CIP, ENR, S, E,TE, CN & + & + & + & + & + \\
\hline 5 & O119:H4 & AMC,CIP, ENR, S, E, NOR,TE & + & - & + & + & + \\
\hline 6 & O63:H5 & P, AMC,CIP,ENR, S, E, NOR,TE & + & - & + & + & + \\
\hline 7 & O157:H7 & AMC, CIP,CN, S, E, ENR,NOR,TE & + & + & + & & + \\
\hline 8 & O86:H9 & P, AMC,CIP,ENR, S, CN,NOR,TE & + & + & + & + & + \\
\hline 9 & O18:H6 & P, AMC, NOR,TE, CIP, ENR & + & + & - & + & + \\
\hline 10 & O158:H10 & P, NOR, S, E, TE,CN,CIP, AMC & - & + & + & + & + \\
\hline
\end{tabular}

Table 10: Relation between resistance profiles and genotypic characterization of some virulence and antibiotic resistance genes of $S$. aureus isolates.

\begin{tabular}{cccccc}
\hline ID & Resistance profile & \multicolumn{2}{c}{ Virulence genes } & \multicolumn{2}{c}{ Antibiotic resistance genes } \\
\cline { 3 - 6 } & & Spa & clfA & NorA & blaz \\
\hline 1 & TE, P, NOR, ENR, E, S, AMC & + & + & + & + \\
\hline 2 & TE, P, NOR, ENR, E, S, AMC,CIP & + & + & + & + \\
\hline 3 & TE, P, NOR, ENR, E, S, AMC,CIP & + & + & + & + \\
\hline 4 & P, CIP, S, TE, E, NOR,AMC & + & + & + & + \\
\hline 5 & TE, P, NOR, ENR, E, S, AMC & + & + & + & + \\
\hline 6 & NOR, ENR, E, S, AMC, TE & + & + & + & + \\
\hline 7 & TE, NOR, ENR, E, S, AMC & + & + & + & + \\
\hline 8 & P, NOR, ENR, E, AMC, S & + & - & + & + \\
\hline 9 & P, NOR, ENR, S, AMC, TE, E & + & - & + & + \\
\hline 10 & TE, P, NOR, ENR, E, S, AMC & + & + & + & + \\
\hline
\end{tabular}


Table 11: Clinical Findings in pneumonic and apparently healthy calves.

\begin{tabular}{|c|c|c|}
\hline Groups and Clinical signs & Apparently healthy calves (40) & Pneumonic calves $(90)$ \\
\hline Temperature $\left({ }^{\circ} \mathrm{C}\right)$ & $37.11 \pm 0.18$ & $39.4 \pm 0.19^{*}$ \\
\hline R.R. (Cycle/Min.) & $12.1 \pm 0.26$ & $21.5 \pm 0.53^{*}$ \\
\hline H.R. (Beat/Min.) & $52.7 \pm 2.9$ & $79.0 \pm 1.98 *$ \\
\hline Nasal discharge & Absent & $\begin{array}{l}\text { Mucoid (36/90) Muco-purulent (33/90) } \\
\text { Absent (6/90) }\end{array}$ \\
\hline Cough & Absent & $\begin{array}{c}\text { Dry cough (12/90) Moist cough (54/90) } \\
\text { Absent (9/90) }\end{array}$ \\
\hline Tracheal sound & Normal & Tracheal rales $(51 / 90)$ \\
\hline Lung sound & Normal vesicular sound & $\begin{array}{c}\text { Crackles (15/90)Wheezes (42/90) } \\
\text { Exaggerated vesicular sound (4/90) Mixed (6/90) }\end{array}$ \\
\hline
\end{tabular}

Abbreviation: R.R: Respiratory Rate; H.R: Heart Rate Significant differences in the values between the diseased and control groups were indicated by $*$ Significant $\mathrm{P}<0.05$

Table 12: Mean values \pm SD of blood cell parameters of the pneumonic calves compared to the control healthy group.

\begin{tabular}{|c|c|c|c|c|c|}
\hline \multirow[b]{2}{*}{$\begin{array}{c}\text { RBCs } \\
\text { Parameters }\end{array}$} & \multicolumn{2}{|c|}{ Group $(\mathrm{N}=130)$} & \multirow[b]{2}{*}{$\begin{array}{c}\text { WBCs } \\
\text { Parameters }\end{array}$} & \multicolumn{2}{|c|}{ Group $(\mathbf{N}=130)$} \\
\hline & $\begin{array}{c}\text { Apparently } \\
\text { healthy calves } \\
\text { (40) }\end{array}$ & $\begin{array}{c}\text { Pneumonic calves } \\
(90)\end{array}$ & & $\begin{array}{c}\text { Apparently } \\
\text { healthy calves } \\
(\mathbf{4 0})\end{array}$ & $\begin{array}{l}\text { Pneumonic } \\
\text { calves }(90)\end{array}$ \\
\hline $\operatorname{RBCs}\left(\times 10^{6} / \mu 1\right)$ & $9.46 \pm 0.59$ & $7.93 \pm 0.62 *$ & TLC $\left(\times 10^{3} / \mu \mathrm{l}\right)$ & $12.35 \pm 1.25$ & $17.95 \pm 2.72 *$ \\
\hline $\mathrm{Hb}(\mathrm{g} / \mathrm{dl})$ & $12.96 \pm 1.25$ & $9.95 \pm 1.72 *$ & Neutrophils \% & $43.22 \pm 2.33$ & $57.28 \pm 2.84 *$ \\
\hline $\operatorname{PCV}(\%)$ & $25.32 \pm 1.45$ & $26.81 \pm 1.37$ & Lymphocytes \% & $46.92 \pm 3.51$ & $30.39 \pm 2.71 *$ \\
\hline MCV (fl) & $21.46 \pm 1.33$ & $36.62 \pm 2.15^{*}$ & Basophils \% & $1.28 \pm 0.29$ & $1.31 \pm 0.33$ \\
\hline $\mathrm{MCH}(\mathrm{pg})$ & $12.67 \pm 0.93$ & $10.12 \pm 0.93^{*}$ & Eosinophils \% & $4.28 \pm 1.25$ & $5.72 \pm 1.25$ \\
\hline $\mathrm{MCHC}(\%)$ & $31.94 \pm 1.15$ & $28.29 \pm 1.52 *$ & Monocytes \% & $4.42 \pm 1.18$ & $5.25 \pm 0.24$ \\
\hline
\end{tabular}

Significant differences in the values between the diseased and control groups were indicated by* Significant $\mathrm{P}<0.05$

Table 13: Mean values \pm SD of Changes in serum biochemical parameters of the pneumonic calves compared to the control healthy group.

\begin{tabular}{ccc}
\hline \multirow{2}{*}{ Parameters } & \multicolumn{2}{c}{ Group $(\mathbf{N}=\mathbf{1 3 0})$} \\
\cline { 2 - 3 } & Apparently healthy calves (40) & Pneumonic calves (90) \\
\hline ALT (U/L) & $38.48 \pm 1.41$ & $69.21 \pm 1.97^{*}$ \\
\hline AST (U/L) & $84.35 \pm 2.85$ & $101.34 \pm 4.35^{*}$ \\
\hline creatine phosphokinase (U/L) & $4.1 \pm 1.2$ & $5.2 \pm 1.8$ \\
\hline Urea (mg/dl) & $23.56 \pm 2.88$ & $36.7 \pm 3.69^{*}$ \\
\hline Creatinine (mg/dl) & $1.10 \pm 0.06$ & $1.63 \pm 0.05^{*}$ \\
\hline Glucose (mmol/l) & $6.2 \pm 1.30$ & $4.6 \pm 0.92$ \\
\hline
\end{tabular}

Significant differences in the values between the diseased and control groups were indicated by* Significant $\mathrm{P}<0.05$

Table 14: Mean values \pm SD of serum total protein and protein electrophoresis in the pneumonic calves compared to the control group.

\begin{tabular}{ccc}
\hline \multirow{2}{*}{ Parameters } & \multicolumn{2}{c}{ Group $(\mathbf{N}=\mathbf{1 3 0})$} \\
\cline { 2 - 3 } & Apparently healthy calves (40) & Pneumonic calves (90) \\
\hline $\mathrm{TP}(\mathrm{g} / \mathrm{dl})$ & $79.16 \pm 5.37$ & $71.3 \pm 3.58^{* *}$ \\
\hline $\mathrm{Alb}(\mathrm{g} / \mathrm{dl})$ & $41.4 \pm 2.09$ & $30.4 \pm 3.15^{* *}$ \\
\hline $\mathrm{Glob}(\mathrm{g} / \mathrm{dl})$ & $37.7 \pm 3.11$ & $41.92 \pm 4.09^{* *}$ \\
\hline $\mathrm{A} / \mathrm{G} \mathrm{ratio}$ & $1.09 \pm 0.17$ & $0.732 \pm 0.15^{* *}$ \\
\hline $\mathrm{a}_{1}$ globulins $(\mathrm{gm} / \mathrm{dl})$ & $10.6 \pm 1.39$ & $11.9 \pm 2.15^{* *}$ \\
\hline $\mathrm{a}_{2}$ globulins $(\mathrm{gm} / \mathrm{dl})$ & $3.4 \pm 0.72$ & $4.1 \pm 0.79^{* *}$ \\
\hline$\hat{\mathrm{a}}_{1}$ globulins $(\mathrm{gm} / \mathrm{dl})$ & $6.8 \pm 0.79$ & $7.6 \pm 1.86^{*}$ \\
\hline$\hat{\mathrm{a}}_{2}$ globulins $(\mathrm{gm} / \mathrm{dl})$ & $5.2 \pm 1.12$ & $6.1 \pm 1.93^{*}$ \\
\hline $\mathrm{a}_{\text {alobulins }(\mathrm{gm} / \mathrm{dl})}^{11.6 \pm 2.94}$ & $13.2 \pm 4.27^{* *}$
\end{tabular}

Significant differences in the values between the diseased and control groups were indicated by

* Significant $\mathrm{P}<0.05 * *$ Highly significant $\mathrm{P}<0.01$ 
Table 15: Electrolyte profile and trace elements status (mean values \pm SD) in the tested calves with Pneumonia.

\begin{tabular}{ccc}
\hline \multicolumn{1}{l}{ Groups } & \multirow{2}{*}{ Apparently healthy calves (40) } & Pneumonic calves (90) \\
\hline Elements & & \\
\hline $\mathrm{Na}(\mu \mathrm{M} / \mathrm{L})$ & $159.17 \pm 11.9$ & $110.90 \pm 9.60^{*}$ \\
\hline $\mathrm{K}(\mu \mathrm{M} / \mathrm{L})$ & $4.98 \pm 0.73$ & $3.82 \pm 0.92$ \\
\hline $\mathrm{Ca}(\mathrm{mg} / \mathrm{dl})$ & $2.89 \pm 0.21$ & $2.48 \pm 0.14$ \\
\hline $\mathrm{Mg}(\mu \mathrm{M} / \mathrm{L})$ & $0.93 \pm 0.11$ & $0.80 \pm 0.16$ \\
\hline $\mathrm{P}(\mu \mathrm{M} / \mathrm{L})$ & $2.91 \pm 0.35$ & $2.01 \pm 0.14^{*}$ \\
\hline $\mathrm{Fe}(\mathrm{mg} / \mathrm{dl})$ & $23.0 \pm 3.2$ & $18.0 \pm 2.3^{*}$ \\
\hline $\mathrm{F}(\mathrm{g} / \mathrm{L})$ & $3.98 \pm 0.82$ & $8.23 \pm 1.96^{*}$
\end{tabular}

Significant differences in the values between the diseased and control groups were indicated by $*$ Significant $\mathrm{P}<$ 0.05Calcium ( $\mathrm{Ca}, \mathrm{mmol} / \mathrm{l})$, Magnesium ( $\mathrm{Mg}, \mathrm{mmol} / \mathrm{l})$, Sodium ( $\mathrm{Na}, \mathrm{mmol} / \mathrm{l})$, Potassium $(\mathrm{K}, \mathrm{mmol} / \mathrm{l})$, Fibrinogen $(\mathrm{F}, \mathrm{g} / \mathrm{l})$ and Iron $(\mathrm{Fe}, \mu \mathrm{mol} / \mathrm{l})$ phosphorus $(\mathrm{P}(\mu \mathrm{M} / \mathrm{L})$.
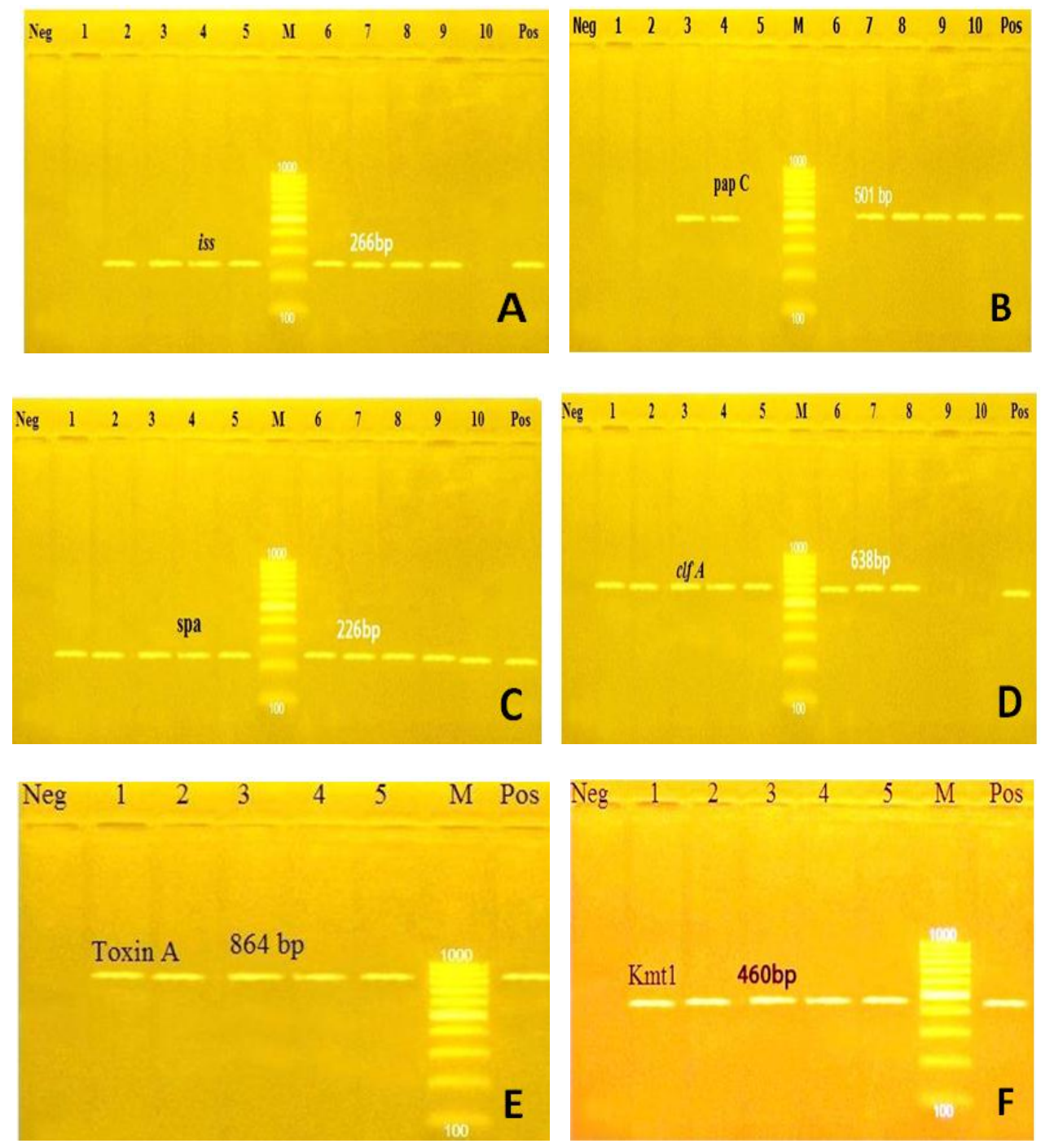

Fig. (1): Shows agarose gel electrophoresis of PCR amplified products of (A\&B): iss and papC virulance genes of E.coli isolates, (C\&D) spa and clf $A$ virulance genes of S.aureus isolates, (E\&F): toxin A and kmt $_{l}$ virulance genes of Past.multocida isolates. Lane M: DNA molecular size marker (100 bp), lanes 1-10: The examined isolates except (E\&F): lanes 1-5 of Past.multocida isolates, lane (+ve): positive control and lane (-ve): negative control. The size in base pairs (bp) of each PCR product is indicated above the bands. 

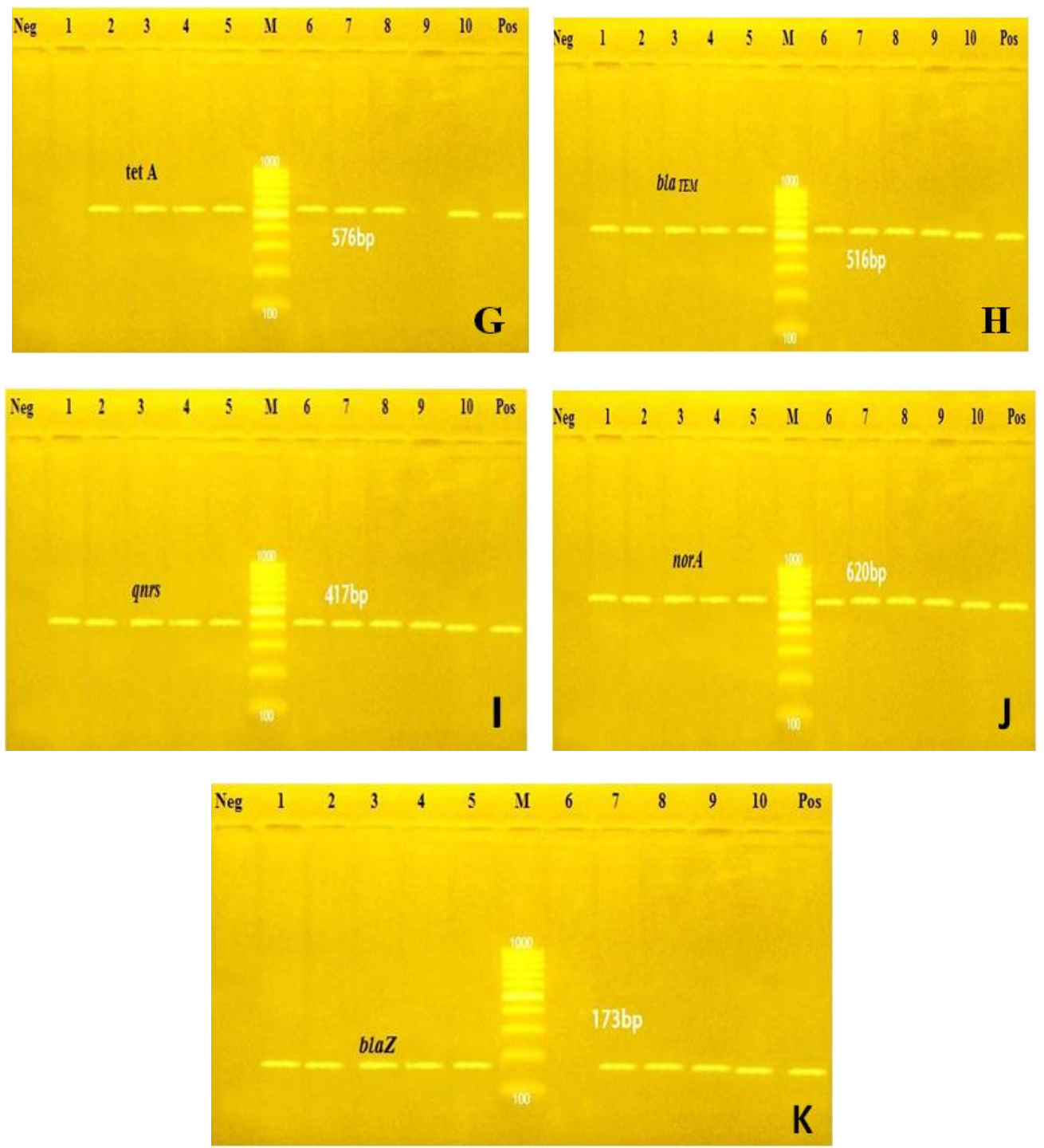

Fig. (2): Shows agarose gel electrophoresis of PCR amplified products of (G\&H\&I): tet $A$, bla $a_{T E M}$ and $q n r S$ antibiotic resistance genes of E.coli isolates, (J\&K) norA and blaz antibiotic resistance genes of S.aureus isolates. Lane M: DNA molecular size marker (100 bp), lanes 1-10: The examined isolates, lane (+ve): positive control and lane (-ve): negative control. The size in base pairs (bp) of each PCR product is indicated above the bands.

\section{DISCUSSION}

Respiratory diseases constitute the most frequently causes of high morbidity and mortality in calves (Radostits et al, 2007). Generally, they are a complex syndrome that involve stress and environmental factors, bacterial, fungal and viral infections which usually could develop when the immune system of the animal is compromised or if the calf has a concurrent bacterial or viral infection (Shahrour, 2003).

E. coli is a major frequent causative agent of pneumonia in calves (El-Shabrawy, 2005). In addition, $S$. aureus is a commensal of mucous membranes especially in the respiratory tracts in humans and animals (Carter, 1986) and most commonly isolated from pneumonic calves (Ismail et al., 1993) and also, Past. Multocida is more frequently associated with pneumonia in dairy calves (Bryson, 1985).

Bacteriologically, in this study, the prevalence ratio of isolated pneumonic bacterial pathogens was: $E$. coli (34.6\%), S. aureus (28.5\%) and Past. multocida (13.1\%). Enany et al. (2012) revealed the predominance of $E$. coli $(36.14 \%)$ in 70 nasal swabs of buffloe calves wher as Sayed and Zaitoun (2009) indicated that S. aureus $(22.43 \%)$ is the predominant isolate among bacterial species from pneumonic calves; meanwhile $E$. coli and $P$. multocida were found in lower percentages (18.22\%) and (15.89\%), respectively. Kassahun Gebremeskel et al. (2017) 
isolated S. aureus $(22.43 \%)$ and E.coli $(18.22 \%)$ but in lower percentages. Also, Seker and Yardimci, (2010) isolated E.coli (16.2\%), S. aureus (16.3\%) and Past. Multocida (8.4\%) among the 165 Gram positive and Gram negative bacterial isolates from the nasal cavity of buffalo calves. The variation in the isolation rates could be attributed to the change of hygienic, management factors and immune status of the animals (Sedeek and Thabet, 2001).

E. coli serotyping in (Table 5) showed that however, most frequently isolated $E$. coli strains in this study were extra-intestinal pathogenic E. coli (ExPEC). Smith et al. (2007) confirmed that ExPEC strains possess virulence traits that allow it to invade, colonize, and induce disease in body sites outside of the gastrointestinal tract when they leave the GI tract and infect other parts of the body such as the urinary tract, the blood, or the lungs, illness results causing infections and illness in other extraintestinal locations in human and animals (pneumonia, urinary tract infections, neonatal meningitis).

The results of pathogencity test of the isolated Past. multocida in mice (Table 6) indicated that they were pathogenic. These results agree with previously mentioned with Enany et al. (2012) and Varte et al. (2014) who reported that all the field isolates of Past. Multocida were found pathogenic for mice and killed the mice inoculated within 6-24 hours post-infection.

Both E.coli and S. aureus isolates developed high resistance levels against different used antimicrobials but Past. multocida exhibited low resistance rates (Table 7). Generally, the resistance to the antimicrobial agents is likely related to their widespread and unreasonable use in the veterinary field. Enany et al. (2012), Ouchriah et al. (2015) and El-Shehedi et al. (2016) confirmed high antimicrobial resistance of the same isolated strains from nasal and lung samples of calves.

The presence of multiple virulence factors increases the virulence potential of bacterial strains. The virulence genes were detected using species specific primer with PCR technique for the recovered isolates. Extra-intestinal pathogenic E. coli virulence potential is attributed to the presence of specialized virulence factors that help the microorganism to cause the disease (Sabarinath et al., 2011). The iss gene has a vital role in the pathogenicity of $E$. coli and could be a potential target for developing novel therapeutics and prevention strategies. Moreover, pap $\mathrm{C}$ gene, the main functional gene of $\mathrm{P}$ pilus, is involved in adhesion of pathogenic $E$. coli to the host cells. The prevalence of issand pap $\mathrm{C}$ virulence genes of $E$. coli isolates were $80 \%$ and $60 \%$ of the isolates. Higher prevalence (100\% and $81.8 \%)$ of iss and pap C among E. coli isolates were recorded by Ammar et al. (2015).
$S$. aureus encodes many proteins that act as virulence factors. Among these virulence factors: $S p A$ and $C l f A$ are important for the ability of $S$. aureus to adhere to and invade host cells as well as to evade host immune responses (Stutz et al., 2011). Moreover, the spa gene is an important virulence factor of $S$. aureus because it is useful for the identification and typing of methicillin resistant $S$. aureus (MRSA) (Dag Harmsen et al., 2017). In the current study, all the isolated strains of $S$. aureus were MRSA that impair the opsonisation process by serum complement and phagocytosis by polymorphonuclear leukocytes. Clumping factor A (Clf A gene) was detected in $80 \%$ of the isolates. Clf A gene is one of the essential adhesion and virulence factors for $S$. aureus (Heilmann, 2011).

Toxigenic and non-toxigenic Past.multocida isolates couldn't be differentiated by morphology or standard biochemical reactions. PCR is accurate, rapid and specific for detection of toxigenic Past. multocida (Carol et al., 1996). Some virulence factors such as dermonecrotoxin are essential for the virulence and pathogencity of Past. Multocida strains (Tox A gene) and KMT1 gene, which is used for confirmation of Past. Multocida identification with PCR (Townsend et al., 2001). Also, Ranjan et al. (2011) described that toxA gene could be useful for direct analysis of toxigenic Past. multocida. In this study, the characteristic bands for both genes were observed at 460 and 864 bp in all tested isolates. El-Shehedi et al. (2016) reported Tox A gene association with the diseased status of the animal.

The obtained results of antimicrobial sensitivity tests revealed that the high resistance rates of $E$. coli isolates against amoxicillin clavulanic acid, penicillin, ciprofloxacin and sulphamethoxazole (100\% each). In the same way, $100 \%$ resistance rate of $E$. coli isolates against sulfamethoxazole and amoxicillin clavulanic acid was recorded with (Ammar et al., 2015). Penicillin and norofloxacin exhibited high resistance levels (100\% of each) against the tested $S$. aureus isolates and $(90 \%)$ for tetracycline Similarly, Abd-Al-Azeem et al. (2013) stated that the highest resistance of $\beta$-lactam resistant $S$. aureus isolates was for penicillin and the lowest was for amoxicillin clavulanic acid. All tested strains of Past. Multocida were highly sensitive against the mostused antibiotics except low resistance was recorded against tetracycline $(41 \%)$ followed by enerofloxacin and norfloxacin antibiotics (30\%). Similarly, Carty et al. (2005) reported that gentamicin was highly effective $(87.5 \%)$ against Past. multocida isolates and they recorded their acquired resistance to enrofloxacin. ElShehedi et al. (2016) indicated the high sensitivity of Past. Multocida isolates to ciprofloxacin, gentamicin and moderate sensitivity to enerofloxacin and norfloxacin. 
The phenotypic resistant pattern was in parallel to the genotypic detection of their antibiotic resistance genes. The phenotypic resistance of $E$. coli isolates to amoxicillin-clavulanic acid and ciprofloxacin compounds could be explained by the presence of bla $_{\text {TEM }}$ and qnrS resistance genes among the twenty examined isolates. Colom et al. (2003) and Eid and Erfan, (2013) recorded the high incidence rates of bla $_{\mathrm{TEM}}$ gene in $E$. coli isolates were previously recorded in Spain and Egypt 88\% and 79\%, respectively. Tetracycline resistance is generally caused by the acquisition of a tetracycline resistance (tet) gene, as these genes are associated with primary resistance mechanisms, which involve active efflux pumps, ribosomal protection, and enzyme inactivation (Koo and Woo 2011). In the present study, tetA was found in $80 \%$ of $E$. coli isolates. This result was in paralleling with Sengelov et al. (2003) who elucitad thattet (A) gene was the most abundant $(71 \%)$ of $100 \mathrm{E}$. coli isolates from diseased and healthy pigs, cattle and broiler chickens.

The multidrug efflux pump NorA is one of the most studied efflux systems in $S$. aureus. Increased resistance to fluoroquinolones had been associated with NorA-mediated efflux, via the increased expression of the norA gene (Costa et al., 2013). NorA, in this study, is exhibited in $100 \%$ of $S$. aueus isolates that were phenotypically resistant to norofloxacin. However, blaZ gene (encodes for $\beta$ lactamase); have been frequently reported in many isolates of $S$. aureus $(90 \%)$. It acts through hydrolysis of the peptide bond in the $\beta$-lactam ring (Jensen and Lyon, 2009). Yang et al. (2005) and Martini et al. (2017) recorded that $94.6 \%$ and $97 \%$ carried blaZ gene respectively among the penicillin resistant $S$. aureus isolates.

The observed respiratory signs in our study come in parallel with Radostitis et al. (2007) and Smith, (2015), which attributed to excessive formation and accumulation of ammonia especially in bad ventilated houses, leading to irritation and inflammation of mucous membranes inducing nasal discharge, and dramatic abnormal rales.

The effect of pneumonia on red cell parameters were significant decrease in RBCs count, $\mathrm{Hb}, \mathrm{PCV}, \mathrm{MCV}$, $\mathrm{MCH}$ and $\mathrm{MCHC}$ values in the diseased group indicating the presence of microcytic hypochromic anemia. The hematological examination showed anemia in pneumonic bovine calves that might be attributed to the destruction of red blood cells by microorganism secretions (Mondal et al., 2004). Anemia may be due to anorexia observed with pneumonia or sequestration of iron in bone marrow macrophages and hepatocytes during infection, thus become unavailable for utilization in hemoglobin synthesis leading to inhibition of erythropoiesis (Mosa, 2000). Decreases iron transfer into developing erythroid cells in bone marrow leading to reduction of
Hbsynthesis and production of microcytic hypochromic RBCs (El-Naser and Khamis, 2009 and Aytekin et al., 2011).

Moreover, the significant increase of TLC and neutrophils might be attributed to inflammatory lesions and presence of bacterial infection (Abou ElGheit, 2000). On the other hand, the significant decrease of lymphocytes might be attributed to the stimulation of adrenal gland during stress with the tissue invaded by bacterial toxins (Abou El-Gheit, 2000). Eosinophilia could be the result of E. coli and Staph.aureus microorganisms (Raghib et al., 2004).

The significant increase of serum enzymes AST and ALT levels in our study might be attributed to the degenerative and necrotic changes in liver and kidney accompanied the formation of pulmonary lesion due to bacterial infection and its toxin. These agree with Abou ElGheit (2000) and Saleh and Allam (2014). Higher CK activity was recorded in infected calves probably as a result of increased breathing rate and increased muscle activity in the course of prolonged duration of severe respiratory disease or consequence of dystrophic damage of muscles during longer lasting recumbency. Elevation of the AST and CK activity was also observed by Abdullah et al. (2013).

The significantly $(\mathrm{P}<0.05) \quad$ increased in urea concentration could be explained by the accelerated catabolism of body protein to compensate anorexia and could be due to infection, while the significant $(\mathrm{P}<0.05)$ increased in serum creatinine might be attributed to kidney dysfunction after infection (Radostits et al., 2000).

The observed highly significant decreased $(\mathrm{P}<0.01)$ in total proteins might be attributed to isolated bacteria or bacterial toxins that increase capillary permeability escaping of plasma proteins into tissues, (Omran et al., 2005). However, the observed highly significant $(\mathrm{P}<0.01)$ decreased albumin level was agreed with Civelek et al. (2007) and El-Deeb, (2011). Furthermore, it could be attributed to anorexia associated with pneumonia and inability of liver to synthesize protein. The hyperglobulinemia might be due to the stimulation of immune system by the infectious agent (Abd El-Raof and Hassan, 1999). The $A / G$ ratio in the pneumonic calves was significantly lower. In our study, comparison of serum protein fractions between healthy and diseased animals showed significantly higher concentrations of $\alpha 1$-globulins in the pneumonic calves. Cerón et al. (2011) indicated that increased $\alpha$-globulin concentrations were indicative of acute inflammation. Tymchak, (2010) reported that chronic infections might produce an increase not only in globulin fractions, predominantly in $\gamma$-globulins, but also in $\alpha$ and $\beta$-globulin fractions, which was accompanied by a decrease of albumin. In addition Stockholm and Scott (2008) elucidated that decreased albumin and 
increased globulin concentrations were the most common pattern in animals with inflammatory diseases. This shift in albumin and globulin concentrations resulted in significantly lower $A / G$ ratio in calves affected by chronic respiratory diseases. In our study in diseased calves had significantly lower mean concentration of serum glucose. This may be due to longer lasting inadequate feed intake and energy supply during times of illness. Decreased concentrations of glucose were reported by Hanzlicek et al. (2010) during experimentally induced pneumonia in calves.

The analytic study indicated significantly lower mean values in the serum concentrations of $\mathrm{Mg}, \mathrm{P}$, and $\mathrm{Fe}$ in diseased calves. Fraser et al. (2014) found a significant decrease of $\mathrm{K}$ and $\mathrm{P}$ concentrations in Mycoplasma bovis and in $\mathrm{Ca}$ and $\mathrm{Na}$ concentrations in calves after experimentally induced pneumonia. Significant differences between healthy calves and calves with pneumonia with lower values of $\mathrm{Ca}$ and $\mathrm{K}$ in diseased animals were recorded by Ragbetli et al. (2010). Hanzlicek et al. (2010) found evident changes in the concentrations of $\mathrm{K}$ (decrease of values) in pneumonia. The decrease in serum calcium might be the result of anorexia, decreased intestinal absorption or increased renal excretion (Radostitis et al., 2007). Approx. 40-45\% of calcium is protein bound mainly to albumin, so hypoalbuminemia might be a possible cause for this hypocalcemia (Kaneko et al., 2008). The significant decrease in serum phosphorous concentrations seemed to be secondary to reduced phosphorus absorption from the gut and reduced phosphorus resorption from the tissues (Orr et al., 1990). The significant decrease in serum iron $(\mathrm{Fe})$ in pneumonic calves agrees with Blum et al. (1996) who revealed decreased concentrations of blood plasma iron in calves with chronic pneumonia. These decreased Fe could be due to reduction of energy and protein intake or sequestration of iron in bone marrow macrophages and hepatocytes during infection, (Kaneko et al., 2008). Decreased appetite might explain the lower serum concentrations of phosphorus and magnesium in calves, both are much more dependent on dietary intake (Rowlands, 1980).

Fibrinogen is considered a consistent marker of bacterial infection and inflammation in domestic ruminants (Youssef et al., 2015). Significantly higher values of plasma fibrinogen $(\mathrm{F})$ concentrations were detected in the diseased calves compared to the respective control group. This elevation may be attributed to the involvement of $\mathrm{F}$ in modulating hemostasis, inflammatory response, and the tissue repairing process (Feldman et al., 2000).

In conclusion, this study provided a nucleus of information regarding bacteria encountered in the upper respiratory tract of calves. Although they are normal flora in the upper reparatory tract, they may help in the progress of calves' pneumonia especially if they are accompanied with presence of risk factors. Alteration hemato-biochemical parameters could be useful diagnostic tools treatment for pneumonia in cattle calves. The study of a correlation between the phenotypic and genotypic antimicrobial resistance and virulence genes among the recovered isolates could be effective for understanding the dangerous spread of virulence genotypes and antibiotic resistance of these species. Recommendations for minimizing the non-responsible use of antibiotics for treatment of pneumonia in calves' farms should be applied to avoid more dissemination of the multidrugresistant bacteria.

\section{REFRENCES}

Abd-Al-Azeem, M.W.; Shaheen, H.M.; AbdelHameed, K.G. and Helmy, M.M. (2013): Penicillin resistance against Staphylococcal isolates recovered from subclinical mastitis in Sohag City, Egypt. Am. J. Res. Commun. 1, 116-130.

Abd El-Latif, M.M. and El-Dessouky, S.A. (2006): Studies on some bacterial causes and blood serum biochemical changes of respiratory affections in lambs. Assiut Vet. Med. J. 52(108): 170-182.

Abd El-Raof, Y.M. and Hassan, H.Y. (1999): Ultrasonography and other aids for calf pneumonia diagnosis. $5^{\text {th }}$ Sci. Cong. Egy. Soci. Cattle Dis. Assuit, Egypt.

Abdullah, F.F.J.; Osman, A.Y.; Adamu, L.; Zakaria, Z.; Abdullah, R.; Zamri-Saad, M. and Saharee, A.A. (2013): Haematological and biochemical alterations in calves following infection with Pasteurella multocida Type B: 2, bacterial lipopolysaccharide and outer membrane protein immunogens (OMP). Asian J Anim Vet Adv 8: 806-813.

Abou El-Gheit, A.I.A. (2000): "Liver and kidney functions in healthy and diseased small ruminant", M.V.Sc. thesis Faculty of Veterinary Medicine, Zagazig University.

Almujalli, AM.; El-Deeb, WM.; Eljalii, EM.; Fouda, TA. and Aibiwy, M. (2015): Clinical, Biochemical and Bacteriological Investigation of Pneumonia in Calves with Special Reference to Alpha-1-Acid Glycoprotein Response. Int. J. Vet. Health Sci Res. 3(5), 6063

Ammar, A.M.; Abd el-hamid, M.I.; Eid, S.E.A. and El oksh, A.S. (2015): Insights into antimicrobial resistance and virulence genes of emergent multidrug resistant avian pathogenic Escherichia coli in Egypt: How closely related are they? Revue Méd. Vét., 166, 9-10, 304314.

Aytekin, I.; Mamak, N.; Ulucan, A. and Kalinbacak, A. (2011): Clinical, hematological, biochemical and pathological findings in 
lambs with Peste des Petits Ruminants. Kafkas Univ. Vet. Fak. Derg., 17(3): 349-355.

Batavani, R.A.; Ansari, M.H. and Asri, S. (2006): Concentrations of serum total protein and protein fractions during diestrus and pregnancy in Makuii ewes. Comp Clin. Pathol. 15: 227-230.

Bergmeyer, H.U. and Harder, M. (1986): A colorimetric method of the determination of serum glutamic oxaloacetic and glutamic pyruvic transaminase. Clin. Biochem. 24: 481481.

Blum, J.W.; Bruckmaier, R.M. and Moser, M. (1996): Endocrine, metabolic and hematological changes associated with reduced growth performance during chronic pneumonia in calves: a case study. Deut Tierärztl Woch 103: 115-116.

Bryson, D.G. (1985): Calf pneumonia. Vet Clin North Am Food Anim Pract., 1:237-245.

Buxton, A. and Fraser, G. (1977): Animal Microbiology. Blackwell Scientific Publications Ltd. Oxford. London, UK.

Carapeto, M.V.; Barrera, R.; Maňe, M.C. and Zaragoza, C. (2006): Serum $\alpha$-globulin fraction in horses is related to changes in the acute phase proteins. J Equine Vet. Sci. 26: 120-127.

Carol, A.L.; Susan, M.S.; Ruby, M.L.; Dale, D.P. and Eric, R.V. (1996): Direct PCR Analysis for Toxigenic Pasteurellamultocida. Journal Of Clinical Microbiology., 34 (12): 3035-3039.

Carter, G.R. (1986): Essential of Veterinary Bacteriology and Mycology. 3 ed. Lea and Febiger, Philadelphia, U.S.A.

Catry, B.; Haesebrouck, F.; Vliegher, D.S.; Feyen, B.; Vanrobaeys, M.; Opsomer, G.; Schwarz, S. and Kruif, A.D. (2005): Variability in acquired resistance of Pasteurella and Mannheimia isolates from the nasopharynx of calves, with particular reference to different herd types. Microb Drug Resist., 11(4): 387-94.

Cerón, J.J.; Caldin, M. and Martinez-Subiela, S. (2011): Answers to some common questions on serum protein electrophoresis. Vet. Rec, doi: 10.1136/vr.d2689.

Cheryk, L.A.; Hooper-McGrevy, K.E. and Gentry, P.A. (1998): Alterations in bovine platelet function and acute phase proteins induced by Pasterella haemolytica A. Can. J. Vet. Res., 62(1): 1-8.

Civelek, T.; Kav, K.; Camkerten, I.; Celik, A.H. and Acar, A. (2007): Effect of bacterial pneumonia in neonatal calves on serum lipids. Bulletin of the Veterinary Institute in Pulawy, 51, 503507.

CLSI (2011): Performance Standards for Antimicrobial Susceptibility Testing, $21^{\text {st }}$ international supplement. CLSI M100-S21. Clinical and Laboratory Standards Institute, Wayne, PA., USA.
Colom, K.; Pèrez, J.; Alonso, R.; FernándezAranguiz, A.; Lariňo, E. and Cisterna, $R$. (2003): Simple and reliable multiplex PCR assay for detection of $b l a_{\mathrm{TEM}}, b l a_{\mathrm{SHV}}$ and bla $a_{\mathrm{OXA}-1}$ genes in Enterobacteriaceae. FEMS Microbiology Letters., 223: 147-151.

Costa, S.S.; Viveiros, M.; Amara, L. and Couto, I. (2013): Multidrug Efflux Pumps in Staphylococcus aureus: an Update The Open Microbiology Journal., 7: 59-71.

Dag Harmsen.; Heike Claus.; Wolfgang Witte.; Jo"rg Rothgänger.; Hermann Claus.; Doris Turnwald and Ulrich Vogel (2017): Typing of Methicillin-Resistant Staphylococcus aureus in a University Hospital Setting by Using Novel Software for spa Repeat Determination and Database Management. JOURNAL OF CLINICAL MICROBIOLOGY, Dec. 2003, p. $5442-5448$

Doumas, B.T.; Bayse, D.D.; Carter, R.J.; Peters, T. and Schaffer, R. (1981): A candidate reference method for determination of total protein in serum. I. Development and validation. Clin. Chem., 27: 1642-1650.

Duran, N.; Ozer, B.; Duran, G.G.; Onlen, Y. and Demir, C. (2012): Antibiotic resistance genes and susceptibility patterns in staphylococci. Indian J. Med. Res 135, pp 389-396.

Eid, S.E.A. and Erfan, A.M. (2013): Characterization of E. coli associated with high mortality of poultry flocks. Assiut Vet. Med. J., 59, 51-61.

El-Deeb, W.M. (2011): Clinical and biochemical investigation of bacterial bronchopneumonia in Egyptian water buffalo calves: Acute phase proteins and lipoprotein profiles. Lucrări Științifice, 54, Medicină Veterinară (4), 412417.

El-Naser, E.M.A. and Khamis, G.F.A. (2009): Some hematological and blood serum biochemistry associated with respiratory affections in camels. Assiut Vet. Med. J., 55(123): 154-162.

Elsayed, M.S.; El-Bagoury, A.E.M. and Dawoud, M.A. (2015): Phenotypic and genotypic detection of virulence factors of Staphylococcus aureus isolated from clinical and subclinical mastitis in cattle and water buffaloes from different farms of Sadat City in Egypt. Veterinary World, 8: 1051-1058.

El-Shabrawy, Mona, A. (2005): Approaching study on the potential role of pulmonary surfactant in innate lung defense buffalo-calves. J. Egypt. Vet. Med Assoc., 65(2): 185-202.

El-Shehedi, M.A.; Aisha R. Ali; Nagib, H.E. and Eraqi, M. (2016): Virulence Genes and Antimicrobial Resistance Profile of Pasteurella multocida Strains Isolated from Buffaloes., International Journal of Chem Tech Research., 9(10): 306-316.

Enany, M.E.; Riad, E.M. and Wahdan, A. (2012): Bacterial causes of pneumonia in buffalo 
calves. Suez Canal Veterinay Medical Journal., XVII (2): 27-38 .

Fathi, E.; Farahzadi, R. and Imani, M. (2011): Approach to treatment of bronchopneumonia by evaluation of selected acute-phase proteins in calf herds. Comp. Clinc. Pathol., SpringerVerlag London Limited.

Feldman, B.F.; Zinkl, J.C. and jain, N.C. (2000): "Schalm's Veterinary Hematology", $5^{\text {th }}$ (ed.), Lippincott Williams and Wilkins, Philadelphia, London.

Fraser, B.C.; Anderson, D.E.; White, B.J.; Miesner, M.D.; Lakritz, J.; Amrine, D. and Mosier, D.A. (2014): Associations of various physical and blood analysis variables with experimentally induced Mycoplasma bovis pneumonia in calves. Am. J. Vet. Res. 75: 200-207.

French, G.L. (2005): Clinical impact and relevance to antibiotic resistance. Adv. Drug Deliv. Rev., 57: 1514-1527.

Geo, F.B.; Janet, S.B. and Stephen, A.M. (1998): The Staphylococci. Medical Microbiology, 21 st ed. Lange Medical Books LlMcGraw Hill, Medical Publishing Division, London, p: 197

Griffin, D.; Chengappa, M.M.; Kuszak, J. and Mc Vey, D.S. (2010): Bacterial pathogens of the bovine respiratory disease complex. Vet Clin North Am Food Anim Pract. 26: 381-394.

Hanzlicek, G.A.; White, B.J.; Mosier, D.; Renter, D.G. and Anderson, D.E. (2010): Serial evaluation of physiologic, pathological, and behavioral changes related to disease progression of experimentally induced Mannheimiahaemolytica pneumonia in postweaned calves. Am J Vet Res 71: 359-369

Heilmann, C. (2011): Adhesion mechanisms of staphylococci. Adv Exp Med Biol., 715:10523.

Ismail, M.; Jakeen, E.I.; Attia, S.A.; Bagwaata; Soheir and Shoukry (1993): Bacterial cause of respiratory disorders in buffalo-calves in Egypt. Vet. Med. J. Giza, 41(2):95-99

Jensen, S.O. and Lyon, B.R. (2009): Genetics of antimicrobial resistance in Staphylococcus aureus. Future Microbiol., 4(5):565-582.

Kachmar, J.F. and Moss, D.W. (1987): Enzymes. In: Fundamentals of Clinical Chemistry, W.B. Saunders Co, Philadelphia PA. 666- 672.

Kaneko, J.J.; Harvey, J.W. and Bruss, M.L. (2008): Clinical biochemistry of domestic animals, $6^{\text {th }}$ Ed. Academic Press, London, pp. 117-138.

Kassahun Gebremeskel, A.; Sisay Tesema, T.; Awukew Yegoraw, A.; Tesfaye Birhanu, B. and Addisu Mekuria, S. (2017): Isolation and Characterization of Bacterial Species from Respiratory Tracts of Cattle Slaughtered in Addis Ababa City, Central Ethiopia. World Vet. J., 7(1):14-20.

Koo, H.J. and Woo, G.J. (2011): Distribution and transferability of tetracycline resistance determinants in Escherichia coli isolated from meat and meat products. Int. J. Food Microbiol., 145: 407-413.

Kupczynski, R. and Chudoba-Drozdowska, B. (2002): Values of selected biochemical parameters of cows blood during their drying-off and the beginning of lactation. EJPAU Ser Vet Med 5: 225-231

Leech, N.L.; Barrett, K.C. and Morgan, G.A. (2007): SPSS for Intermediate Statistics: Use and Interpretation, Lawrence Erlbaum Asso, USA.

Martini, C.L.; Lange, C.C.; AVP Brito, M. and Ribeiro, J.B. (2017): Characterisation of penicillin and tetracycline resistance in Staphylococcus aureus isolated from bovine milk samples in Minas Gerais, Brazil. 84(2): 202-205.

Momtaz, H.; Rahimi, E. and Tajbakhsh, E. (2010): Detection of some virulence factors in Staphylococcus aureus isolated from clinical and subclinical bovine mastitis in Iran. Afr. J. Biotechnol., 9: 3753-3758.

Mondal, D.; Pramanik, A.K. and Basak, D.K. (2004): Clinico-haematology and pathology of caprinemycoplasmal pneumonia in rain fed tropics of West Bengal. Small Ruminant Research 51: 285-295.

Mosa, Y.B. (2000): Investigation of respiratory problems in calves. M.V.Sc. thesis Fac. Vet. Med. Zagazig University.

NADIS (National Animal Diseases Information Service), (2014): http://www.nadis.org.uk.

Orr, C.L.; Hutcheson, D.P.; Grainger, R.B.; Cummins, J.M. and Mock, R.E. (1990): Serum copper, zinc, calcium and phosphorus concentrations of calves stressed by: bovine respiratory disease and infectious bovine rhinotracheitis. J. Anim. Sci., 68: 2893-2900.

Perkin Elmer (1967): Model 257 Spectrophotometer Instructions.

Pourmand, M.R.; Yousefi, M.; Salami, S.A. and Amini, M. (2014): Evaluation of Expression of NorA Efflux Pump in Ciprofloxacin Resistant Staphylococcus aureus against Hexahydroquinoline Derivative by Real-Time PCR. Acta Med. Iran 2014;52(6):424-9.

Ouchriah, Y.; Heleili, N.; Mamache, B. Ayachi, A. and Kassah, A.L. (2015): Antimicrobial Sensitivity of Bacterial Strains Isolated From Newborn Calves in the Abattoir of Batna (Algeria). International Journal of Livestock Research.,5 (2): 32-42.

Quinn, P.J.; Markey, B.K.; Carter, M.E.; Donnelly, W.J. and Leonard, F.C. (2002): Veterinary Microbiology and Microbial Disease. $1^{\text {st }}$ Ed. Blackwell Publishing Professional, Iowa, pp: 461-464.

Quinton, L.J.; Jones, M.R.; Robson, B.E. and Mizgerd, J.P. (2009): Mechanisms of the hepatic acute-phase response during bacterial pneumonia. Infect. Immun., 77(6): 2417-2426. 
Radostits, O.M.; Gay, C.C.; Blood, D.C. and Hinchcliff, K.W. (2000): Veterinary Medicine, $9^{\text {th }}$ ed. Philadelphia: WB Saunders, P: 832833. Respiratory disease. Anim. Health Res. Rev., 8(2):129-150.

Radostits, O.M.; Gay, C.C.; Hinchcliff, K.W.E. and Constable, P.D. (2007): Veterinary Medicine. A textbook of the diseases of cattle, sheep, goats, pigs and horses, W.B. Saunders Co. pp1698-1771.

Ragbetli, C.; Ceylan, E. and Tanritanir, P. (2010): The effect of tulathromycin treatment on biochemical parameters in Montofon calves with pneumonia. Asian J. Anim Vet. Adv 5: 169-174.

Raghib, M.F.; Said, E.A.; Hassan, M.S. and AlGharabawy, B.S. (2004): Effect of pasteurllosis on health performance and some hematological and blood serum constituents of dromedary camel. Menufiya Vet. J. 3(2): 385395.

Randall, L.P.; Cooles, S.W.; Osborn, M.K.; Piddock, L.J.V. and Woodward, M.J. (2004): Antibiotic resistance genes, integrons and multiple antibiotic resistance in thirty-five serotypes of Salmonella enterica isolated from humans and animals in the UK. Journal of Antimicrobial Chemotherapy. 53, 208-216.

Ranjan, R.; Panda, S.K.; Acharya, A.P.; Singh, A.P. and Gupta, M.K. (2011): Molecular diagnosis of Haemorrhagic Septicaemia-A review. Vet. World, 4:189-192.

Robicsek, A.; Strahilevitz, J.; Jacoby, G.A.; Macielag, M.; Abbanat, D.; Park, C.H.; Bush, $K$. and Hooper, D.C. (2006): Fluoroquinolonemodifying enzyme: a new adaptation of a common aminoglycoside acetyltransferase. Nat Med 12:83-88.

Rock, R.C.; Walker, W.G. and Jenning, C.D. (1987): Nitrogen metabolites and renal function. In: Tietz NW, ed. Fundamentals of clinical chemistry. $3^{\text {rd }}$ ed. Philadelphia: WB Saunders" 669-704.

Rosenberger, G.; Dirksen, H.D.; Grunert, E.; Krause, D.; Stober, M. and Mack, R. (1979): Clinical examination of cattle $1^{\text {st }}$ edition, Verlag Paul Parrey, Berlin and Hamburg.

Rowlands, G.J. (1980): A review of variations in the concentrations of metabolites in the blood of beef and dairy cattle associated with physiology, nutrition and disease, with particular reference to the interpretation of metabolic profiles. World Rev Nutr Diet 35: 172-235.

Sabarinath, A.; Tiwari, K.P.; Deallie, C.; Belot, G.; Vanpee, G.; Metthew, V.; Sharma, R. and Hariharan, H. (2011): Antimicraobial resistance and phylogenetic groups of commensal $E$. coli isolates from healthy pigs in Grenada. Research, Web. Med. central, 7:55:27.
Sadeghian, S.; Dezfouli, M.R.M.; Kojouri, G.A.; Bazargani, T.T. and Tavasoli, A. (2011): Pasteurellamultocida pneumonic infection in goat: Hematological, biochemical, clinical and pathological studies. Small Ruminant Research, 100, 189-194.

Saleh, N.S. and Allam, T.S. (2014): Pneumonia in Sheep: Bacteriological and clinicopathological Studies. American J. of Res. Commun., 2(11): 70-88.

Sambrook, J.; Fritscgh, E.F. and Meniates, T. (1989): Molecular Cloning: A laboratory manual, vol. 1. Cold Spring Harbor Laboratory press. New York.

Sayed, S.M. and Zaitoun, A.M.A. (2009): Aerobic bacterial pathogens of pneumonic feedlot buffalocalves, In Assiut governorate, Egypt. Ass. Univ. Bull. Environ. Res. 12: 55-62.

Sedeek, S.R. and Thabet, A. El-R. (2001): Some studies on bacterial causes of pneumonia in cattle in Assiut Governorate. Assiut Vet. Med. J., 45(90): 243-255.

Şeker, E. and Yardimci, H. (2010): The aerobic bacterial flora of the nasal cavity in healthy Anatolian water buffalo calves. Ankara Üniv Vet Fak Derg, 57:65-67.

Sengelфv, G.; Halling-Sфrensen, B. and Aarestrup, F.M. (2003): Susceptibility of Escherichia coli and Enterococcus faecium isolated from pigs and broiler chickens to tetracycline degradation products and distribution of tetracycline resistance determinants in $E$. coli from food animals. Vet. Microbiol., 95 (12): 91-101.

Shahrour, K.M.Z. (2003): Some studies on respiratory disease complex and diarrhea in newly born calves. Ph.D. Cairo University. Fac. Vet. Med., Department of Medicine and Infectious diseases.

Smiley, S.T.; King, J.A. and Hancock, W.W. (2001): Fibrinogen stimulates macrophage chemokine secretion through toll-like receptor 4 . J. Immunol., 167(5): 2887-94.

Smith, J.L.; Fratamico, P.M. and Gunther, N. (2007): Extraintestinal pathogenic Escherichia coli (ExPEC). Foodborne Pathog. Dis., 4 134-163.

Smith, B.P. (2015): Text Book of Large Animal Medicine. $5^{\text {th }}$ ed. Copyright (C) 2015 by Mosby, an imprint of Elsevier Inc.

Stockholm, S.L. and Scott, M.A. (2008): Proteins. In: Stockholm SL, Scott MA (Eds.): Fundamentals of veterinary clinical pathology. 2nd ed., Blackwell, pp. 369-413

Stutz, K.; Stephan, R. and Tasara, T. (2011): SpA, ClfA, and FnbA genetic variations lead to Staphaurex test-negative phenotypes in bovine mastitis Staphylococcus aureus isolates. J. Clin. Microbiol. 49, 638-646.

Townsend, K.M.; Boyce, J.D.; Chung, J.Y.; Frost, A.J. and Adler, B. (2001): Genetic organization of Pasteurellamultocida cap Loci 
and development of a multiplex capsular .J. Clin. Microbiol., 39: 924-929.

Traute, J.; Christine, S.; Petra, P.; Matthias, V.; Hans, C.P. and Lothar, H.W. (2011): Virulence associated genes in avian pathogenic E. coli (APEC) isolated from internal organs of poultry having died from coolibacillosis. Int. J. Med. Microbiol. 291: 371-378.

Tymchak, L.L. (2010): Amino acids and proteins. In: Bishop ML, Fody EP, Schoeff LE (Eds.): Clinical chemistry: techniques, principles, correlations. Lippincott Williams and Wilkins, Philadelphia, USA, pp. 223-265

Varte, Z.; Dutta, T.K.; Roychoudhury, P.; Begum, J. and Chandra, R. (2014): Isolation, identification, characterization and Antibiogram of Pasteurellamultocida isolated from pigs in Mizoram with special reference to progressive atrophic rhinitis, Veterinary World 7(2): 95-99

Yang, Z.; Wong, W.S. and Nielsen, R. (2005): Bayes empirical bayes inference of amino acid sites under positive selection. Mol. Biol. Evol. 22, 1107-1118.

Young, D.S. (1995): Effect of drugs on clinical laboratory tests, $4^{\text {th }}$ Ed. P: 3-190 to 3-211

Yousef, M.R.; Mahmoud, M.A.; Mohamed, Ali, S. and Al-Blowi, M.H. (2013): Seroprevalence of some bovine viral respiratory diseases among non-vaccinated cattle in Saudi Arabia. Vet World. 6:1-4.

Youssef, M.A.; El-khodery, S.A. and Abdo, M. (2015): A comparative study on selected acute phase proteins (APPs) and immunoglobulins in buffalo and bovine calves with respiratory disease. Comparative Clinical Pathology 24:515-520.

\title{
دراسات بكتيريولوجية وجزيئية واكلينيكية باثولوجية على الالتهاب الرئوى فى العجول مع الاشارة الى الى جينات المقاومة للمضادات الحيوية المابة الترنية
}

\author{
هالة عبل المنعم عبد الحمبل ، غادة عبد العال ابراهيم
}

E-mail: g_abdelaall@yahoo.com Assiut University web-site: www.aun.edu.eg

لقد كان هدف هذه الدر اسة الحالية هو الفحص البكتيرى للعجول المصابة بالالتهاب الرئوى و عمل اختبار الحساسية للمضادات الحيوية

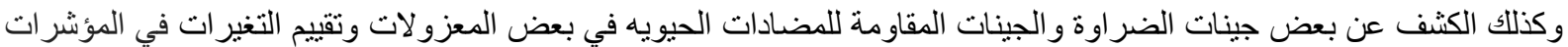

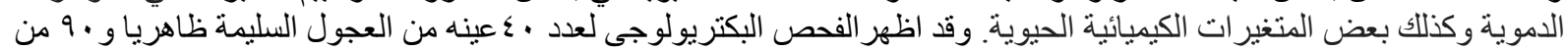

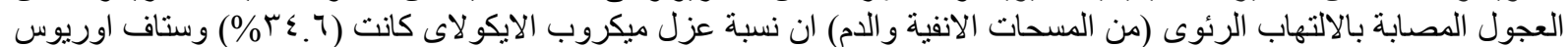

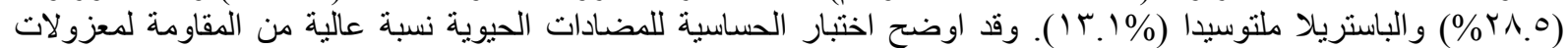

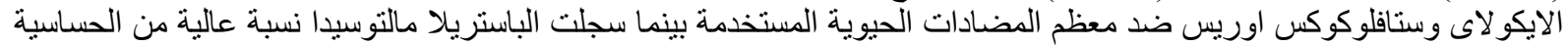

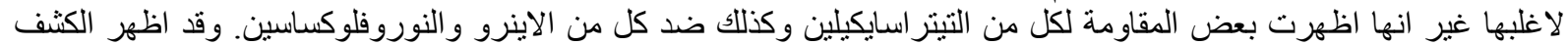

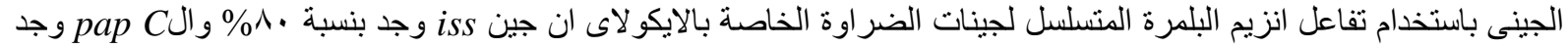

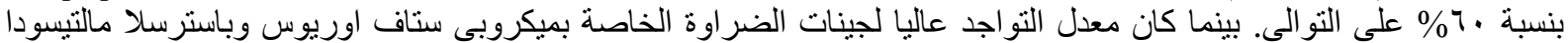

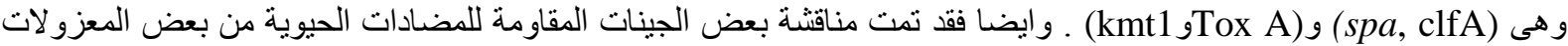

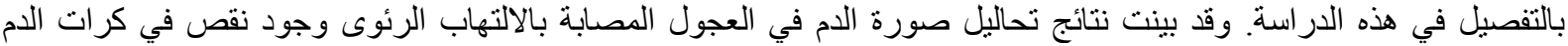

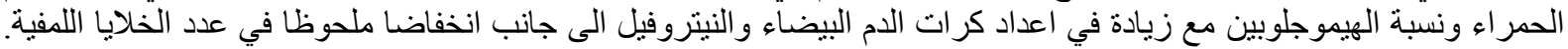

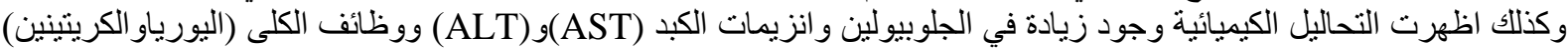

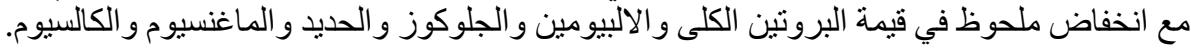

